\title{
RESPON PEMBERIAN MIKORIZA ARBUSKULAR DALAM MEDIA ZEOLIT TERHADAP PERTUMBUHAN DAN HASIL TANAMAN KEDELAI
}

\author{
RESPON OF ARBUSCULAR MYCORRHIZA IN ZEOLITE MEDIUM ON THE GROWTH AND \\ YIELD OF SOYBEAN
}

Usnawiyah dan Khaidir ${ }^{1)}$

\begin{abstract}
Arbuscular mycorrhiza expected to increase the growth and yield of soybean. However, during the application requires another materials as growth media or spores carrier such as compos and zeolite. Zeolites are used as promoters for plant growth and development for the better through the efficient use of fertilizers. These minerals can retain nitrogen content in the soil, improve the quality of solid organic fertilizer and liquid waste. Zeolites can improve the efficiency of fertilizer use, both in stimulating plant growth and development and to increase agricultural output. Furthermore, it will support the work function of arbuscular mycorrhiza as root simbion.
\end{abstract}

Keywords: Arbuscular mycorrhiza, zeolite, plant growing and yield, soybean

\section{PENDAHULUAN}

Pertumbuhan dan hasil produksi komoditi pertanian sangat dipengaruhi oleh ketersediaan unsur hara dalam tanah, baik itu unsur hara makro maupun unsur hara mikro. Upaya untuk menambahkan unsurunsur hara tersebut ke dalam tanah dapat dilakukan melalui pemupukan. Pupuk yang digunakan dapat berupa pupuk kimia, pupuk organik, maupun pupuk hayati.

Penggunaan pupuk kimia dianggap memberikan dampak negatif terhadap keberlangsungan lahan pertanian. Dengan berbagai kerugian yang ditimbulkan akibat penggunaan pupuk kimia (pupuk buatan), masyarakat petani Indonesia sudah mulai berfikir untuk kembali ke zaman sebelum revolusi hijau yang diprakarsai oleh Barat. Petani sudah mulai kembali menggunakan pupuk organik sebagai subsitusi terhadap pupuk buatan. Pupuk organik mengandung bahan-bahan organik alami yang dibutuhkan oleh tanaman untuk pertumbuhan. Bahan organik merupakan komponen penting tanah yang mempengaruhi sifat fisik, kimia, maupun biologi tanah.

Disamping pupuk organik, dewasa ini petani juga sudah mulai menggunakan pupuk hayati sebagai usaha dalam membantu pertumbuhan dan peningkatan hasil-hasil tanaman pertanian. Pupuk hayati adalah biofertilizer (pupuk bio) dan tidak mengandung N, P, dan K. Kandungan pupuk hayati adalah mikrooganisme yang memiliki peranan positif bagi tanaman. Kelompok mikroba yang sering digunakan adalah mikroba-mikroba yang menambat $\mathrm{N}$ dari udara, mikroba yang melarutkan hara (terutama $\mathrm{P}$ dan $\mathrm{K}$ ), mikroba-mikroba yang merangsang pertumbuhan tanaman, diantaranya terdapat jamur. Jamur atau cendawan (fungi) merupakan bagian penting dari pupuk hayati, sebagai contoh adalah mikoriza. Mikoriza merupakan asosiasi simbiotik antara cendawan dengan akar tanaman yang membentuk jalinan interaksi yang kompleks. Terdapat dua (2) tipe dari mikoriza, yaitu ektomikoriza dan endomikoriza. Salah satu subtipe dari endomikoriza adalah mikoriza arbuskular yang dapat berasosiasi dengan $80 \%$ spesies tanaman tingkat tinggi (Barea dan Jeffries, 1995).

Kehadiran mikoriza arbuskular pada akar tanaman dapat meningkatkan penyerapan unsur hara (khususnya hara immobile) dan air, memacu pertumbuhan akar tanaman dari hormon tumbuh yang dihasilkan, melindungi tanaman dari keracunan logam berat, dan meningkatkan ketahanan tanaman dari patogen. Dengan adanya asosiasi ini, mengakibatkan pertumbuhan dan hasil tanaman meningkat (Noertjahyani, 2012).

Salah satu tanaman yang diambil sebagai sampel untuk melihat efek atau pengaruh dari pemberian mikoriza arbuskular adalah tanaman kedelai (Glycine max L). Sampai saat ini kebutuhan kedelai di Indonesia belum dapat mencapai swasembada kedelai setiap tahunnya, sehingga terpaksa diimpor. Produksi kedelai nasional masih rendah, tahun 2007 hanya sebesar 1,3 ton/ha (Adisarwanto, 2008) dan di Aceh Utara produksi kedelai tahun 2006 sebesar 1,2 ton/ha (BPS, 2008).

Maka untuk memenuhi kebutuhan kedelai sekitar 2 juta ton/tahun pemerintah mengimpor 
sekitar 1,2 juta ton atau sekitar $60 \%$ dari kebutuhan nasional.Peningkatan produksi kedelai secara ekstensifikasi berkompetisi dengan penggunaan lahan pertanian untuk kebutuhan non pertanian. Karena itu perluasan lahan pertanian masa mendatang hanya dapat menggunakan lahan-lahan marginal seperti lahan gambut, lahan rawa dan lahan pasang surut. Lahan pasang surut adalah lahan yang genangannya dipengaruhi pasang surut air laut (Hidayat, 2002).Tanaman kedelai sangat prospek sebagai sumber protein nabati di masa yang akan datang, oleh karenanya perlu dilakukan berbagai upaya dalam peningkatan produksi kedelai (Usnawiyah, 2012).

\section{Zeolit sebagai Media Tumbuh dan CarrierSpora Mikoriza Arbuskular}

Media tumbuh mikoriza memiliki ciri-ciri antara lain; tekstur yang kasar, berpasir dengan kapasitas tukar kation (KTK) yang tinggi yang memiliki kemampuan mengurangi tersedianya $\mathrm{P}$. Tanah berlempung dengan struktur yang kurang baik tidak cocok digunakan sebagai media tumbuh mikoriza. Inokulum mikoriza dapat diproduksi pada "vermiculite", gambut, serbuk gergaji, kulit, "perlite", atau campuran dari media tersebut (Suhardi, 1989). Selain bahan di atas, batuan zeolit juga dapat digunakan sebagai media tumbuh dan pembawa (carrier) terhadap spora mikoriza yang telah dipanen (Santoso et.al., 2006). Zeolit itu sendiri mempunyai sifat-sifat meliputi dehidrasi, adsorben, penyaring molekul, katalisator dan penukar ion. Sifat kimia zeolit yang sering dimanfaatkan di bidang pertanian adalah sifat adsorbsi dan sifat pertukaran kation (Polat et al., 2004).

Zeolit dapat menahan air sampai $60 \%$ berat zeolit karena porositas yang tinggi dari struktur kristalin zeolit. Molekul-molekul air di dalam pori-pori zeolit dapat dengan mudah dievaporasi atau diabsorpsi ulang tanpa merusak strukturnya. Zeolit menjamin ketersediaan air secara permanen, memperpanjang ketersediaan kelembaban selama musim kering, dapat mempercepat pembasahan kembali (re-wetting) dan peningkatan penyebaran air secara lateral ke dalam zona perakaran selama proses pengairan berlangsung. Hal ini dapat mempertahankan jumlah air yang dibutuhkan untuk proses pengairan.Lebih lanjut, kapasitas absorpsi yang tinggi membuat zeolit digunakan sebagai pembawa (carrier) dari pestisida-pestisida pertanian (Polat et al. 2004).
Zeolit menyediakan muatan negatif yang merupakan tempat yang ideal untuk kation-kation seperti $\mathrm{Na}, \mathrm{K}, \mathrm{Ba}$, dan $\mathrm{Ca}$, dan gugus-gugus yang bermuatan positif seperti $\mathrm{H}_{2} \mathrm{O}$ dan $\mathrm{NH}_{3}$. Ion-ion karbonat dan nitrat berinteraksi secara fisika melalui muatan negatif di dalam zeolit. Oleh karea itu, kation-kation logam alkali dan alkali tanah dengan jalan yang sama berinteraksi secara fisik dengan zeolit, demikian juga halnya dengan molekul air dapat diserap oleh zeolit (Mumpton 1999).

Kation-kation yang diserap secara relatif tidak tetap akibat interaksi fisiknya yang lemah dapat digantikan (ditukarkan) menggunakan metode pertukaran ion standar sehingga memungkinkan zeolit digunakan sebagai penukar ion yang baik. Pertukaran kation zeolit pada dasarnya adalah fungsi dari derajat substitusi silika oleh aluminium dalam struktur kristal zeolit. Semakin banyak jumlah aluminium menggantikan posisi silika, maka semakin banyak muatan negatif yang dihasilkan, sehingga makin tinggi kemampuan tukar kation zeolit tersebut (Mumpton 1999). Zeolit merupakan salah satu dari banyak bahan penukar kation yang mempunyai kapasitas tukar kation yang tinggi (200 $300 \mathrm{meq} / 100 \mathrm{~g}$ ). Kapasitas tukar kation dari zeolit ini terutama merupakan fungsi dari tingkat penggantian atom aluminium (Al) terhadap silikon $(\mathrm{Si})$ dalam struktur kerangka zeolit (Mumpton 1999).

Berdasarkan uraian di atas, maka selain sebagai media tumbuh dan pembawa (carrier) bagi spora mikoriza arbuskular, zeolit juga ikut membantu dalam usaha peningkatan produksi dan hasil dari tanaman pertanian seperti wortel, apel, terung, gandum (Torii, 1980), padi (Torii, 1980; Suhala dan Arifin, 1997), jagung, maupun tanaman kedelai(Suhala dan Arifin, 1997).

\section{Aplikasi Mikoriza Arbuskular dalam Media Zeolit pada Tanaman Kedelai}

Dalam usaha peningkatan produksi tanaman kedelai, beberapa upaya yang telah dilakukan diantaranya adalah dengan pemberian mikoriza arbuskular sebagai pupuk hayati yang dipadukan dengan bahan-bahan lain seperti media kompos (Noertjahyani, 2012) atau pun media zeolit. Menurut Noertjahyani (2012), peningkatan takaran inokulan mikoriza tidak memberikan pengaruh yang nyata terhadap pertumbuhan dan hasil tanaman kedelai. Namun, pada saat dikombinasikan dengan kompos terdapat interaksi diantara keduanya. Takaran inokulan mikoriza dan kompos memberikan efek berbeda terhadap jumlah polong per tanaman, jumlah 
biji dan bobot biji pertanaman, tetapi tidak terhadap pertumbuhan (tinggi tanaman dan jumlah daun), dan beberapa komponen hasil tanaman (jumlah nodula efektif, nisbah pupus akar, kolonisasi mikoriza, dan bobot 10 butir). Aplikasi kompos 30 ton/ha dan 20 ton/ha disertai dengan aplikasi mikoriza masingmasing dengan takaran $10 \mathrm{~g}$ dan $15 \mathrm{~g}$ per lubang tanam memberikan hasil lebih tinggi dibandingkan perlakukan lain.

Hasil penelitian yang lain menyatakan bahwa, pemberian fungi mikoriza arbuskular sebanyak 7,5 $\mathrm{g}$ micofer/polybag dapat meningkatkan pertumbuhan dan produksi beberapa tanaman kedelai yang lebih tinggi pada tanah salin. Hal ini ditunjukkan dengan meningkatnya pertumbuhan total luas daun, rasio tajuk akar, laju asimilasi bersih, laju tumbuh relatif, derajat infeksi, jumlah polong berisi, serapan $\mathrm{P}$, serapan $\mathrm{N}$, kadar gula dan berat 100 biji (Usnawiyah, 2012).

Penelitian yang dilakukan Usnawiyah (2012) menggunakan mikoriza arbuskular dengan zeolit sebagai media pembawa (carrier) dari spora yang dihasilkan. Ada kemungkinan bahwa, selain mikoriza, zeolit juga ikut mempengaruhi terhadap pertumbuhan dan hasil dari tanaman kedelai. Berdasarkan hasil penelitian yang dilakukan Pusat Pengembangan Teknologi Mineral dengan Fakultas Pertanian Universitas Padjadjaran, bahwa perlakuan terhadap tanah podzolan merah-kuning dengan kalsit dan zeolit memberikan pengaruh nyata, yaitu ; Penambahan 6 ton zeolit dan 2 ton kapur per ha, produksi bijih kedelai kering per ha meningkat $566,4 \%$, atau 1450 ton/ha dibandingkan dengan produksi tanpa penambahan zeolit dan kapur yang besarnya 0,256 ton/ha (Suhala dan Arifin, 1997).

\footnotetext{
Zeolit dapat meningkatkan efisiensi dari penggunaan pupuk, baik dalam merangsang pertumbuhan dan perkembangan tanaman maupun dalam peningkatan hasil pertanian. Zeolit dapat ditambahkan dalam pupuk untuk membantu mengembalikan nutrisi dalam tanah sehingga ada istilah bahwa peningkatan kualitas tanah jangka panjang dilakukan melalui peningkatan daya absorpsi dari zeolit. Tanaman membutuhkan nutrisi-nutrisi penting seperti nitrogen (N) dan kalium (K), kalsium, magnesium, dan unsur-unsur mikro lainnya. Dengan adanya zeolit, zat-zat nutrisi tersebut dapat dipertahankan dalam zona perakaran untuk digunakan tanaman pada saat dibutuhkan (Polat et al., 2004).
}

Secara pasti, pemakaian zeolit bertujuan untuk efisiensi penggunaan pupuk $\mathrm{N}$ dan $\mathrm{K}$ melalui pengurangan laju pemakaian pupuk dengan jalan memperpanjang aktivitasnya yang akhirnya memberi hasil yang lebih tinggi (Polat et al., 2004). Sebagai tambahan, nutrisi penumbuh tanaman di dalam tanah yang mengandung $\mathrm{Pb}, \mathrm{Cd}$, dan $\mathrm{Cu}$ dalam jumlah yang tinggi dapat diproteksi melalui kemampuan absorpsi zeolit. Hasil penelitian juga menunjukkan bahwa $\mathrm{S}^{90}$ yang diambil oleh tanaman berkurang secara signifikan dengan adanya zeolit. Oleh karena itu, aplikasi dari zeolit dalam bidang pertanian akan dapat meningkatkan pertumbuhan dan perkembangan tanaman melalui pengurangan kehilangan nutrisi tanaman yang ada di dalam tanah (Anonimous, 2004).

Selain sebagai pembawa pupuk (carrier fertilizer), zeolit juga berfungsi sebagai bahan pemantap tanah (soil conditioner), pengontrol pelepasan ion $\mathrm{NH}_{4}{ }^{+}$dan $\mathrm{K}^{+}$(slow release fertilizer), dan sebagai pengontrol cadangan air (Suhala dan Arifin, 1997).Ion $\mathrm{NH}_{4}{ }^{+}$dalam tanah dapat diserap oleh zeolit, sehingga secara alami berfungsi sebagai pengatur pelepasan pupuk (slow release fertilizer). Penahanan ion $\mathrm{NH}_{4}{ }^{+}$dalam struktur kristal zeolit dapat mencegah proses oksidasi ion $\mathrm{NH}_{4}^{+}$menjadi ion $\mathrm{NO}_{3}{ }^{-}$oleh nitrifying bacteria. Selain itu, keadaan ini juga dapat mengontrol pemakaian pupuk jenis amonium secara berlebihan. Penggunaan zeolit, telah memperlihatkan hasil, yaitu berupa peningkatan ketersediaan unsur nitrogen dalam tanah. Keberhasilan ini akan lebih terlihat lagi bila zeolit tersebut digunakan pada tanah yang kandungan lempungnya sedikit (sandy soil, coarse textured soils, highly permeable) (Suhala dan Arifin 1997).

Dengan demikian, secara tidak langsung zeolit yang tadinya hanya berfungsi sebagai media tumbuh dan pembawa (carrier) terhadap spora mikoriza arbuskular, ikut membantu dalam peningkatan pertumbuhan dan hasil tanaman kedelai.

\section{KESIMPULAN}

Mikoriza arbuskular diduga dapat meningkatkan pertumbuhan dan hasil tanaman kedelai. Namun, pada saat aplikasi perlu dikombinasikan dengan bahan lain sebagai media tumbuh atau pembawa spora mikoriza tersebut seperti media kompos dan batuan zeolit. Aplikasi zeolit sebagai media tumbuh dan pembawa (carrier) spora didasarkan pada sifat-sifat dari zeolit seperti laju penyerapan (absorpsi) yang relatif tinggi dan 
daya tukar kation (KTK). Penggunaan zeolit sebagai media, akan dapat mengontrol efisiensi penggunaan pupukyang digunakan dalam menjaga pertumbuhan dan perkembangan tanaman agar memperoleh hasil yang lebih baik. Selain itu, zeolit dapat mempertahankan kandungan nutrisi dalam zona perakaran tanaman yang dapat diambil (diserap) oleh tanaman pada saat dibutuhkan. Dengan demikian akan membantu dan mendukung fungsi kerja daripada mikoriza arbuskular yang bersimbiosis dengan akar tanaman.

\section{DAFTAR PUSTAKA}

Adisarwanto. T. 2008. Budidaya Kedelai Tropika. Penebar Swadaya. Jakarta.

[Anonimous]. (2004).

Zeolite. http://www.enlimining.net. [30 Oktober 2012].

Barea, J.M. \& Jeffries, P. 1995. Arbuscular Mycorrhizasin Suistainable Soil Plant Systems. In : Hock B., Varma, A. Eds. Mycorrhiza : Structure, function, molecular biology and biotechnology. Springer verlag.

BPS (Badan Pusat Statistik). 2008. Aceh Utara Dalam Angka. Badan Pusat Statistik. Kabupaten Aceh Utara.

Hidayat. 2002. Potensi Lahan Basah. Pertanian Universitas Tanjung Pura. Akta Agrosia. Vol. 5: (1:60-67)

Mumpton FA. (1999). La roca magica : Uses of natural zeolite in agriculture and industry. Proc Natl Acad Sci 96 : 3463-3470.
Noertjahyani. (2012). Respon Pertumbuhan Kolonisasi Mikoriza dan Hasil Tanaman Kedelai sebagai Akibat dari Takaran Kompos dan Mikoriza Arbuskular. Tanjungsari Sumedang : Fakultas Pertanian Universitas Winaya Mukti.

Polat E, Karaca M, Demir H, Onus AN. (2004). Use of Natural Zeolite (Clinoptilolite) in Agriculture. J Fruit Ornmtl Plant Res 12 : Ed khusus.

Santoso E, Turjaman M, Irianto RSB. (2006). Aplikasi Mikoriza Untuk Meningkatkan Kegiatan Rehabilitasi Hutan Dan Lahan Terdegradasi.Makalah Utama pada Ekspose Hasil-hasil Penelitian : Konservasi dan Rehabilitasi Sumberdaya Hutan. Padang, 20 September 2006.

Suhala S, Arifin M. (1997). Bahan Galian Industri. Bandung : Pusat Penelitian dan Pengembangan Teknologi Mineral. hlm 320338.

Suhardi, 1989. Mikoriza Vesikular Arbuskular (MVA). Pedoman Kuliah. Proyek Peningkatan Perguruan Tinggi. Yogyakarta : Universitas Gadjah Mada.

Torii, K. (1980). Utilization of Natural Zeolit in Japan. Tohoku-Japan : National Industrial Research Institute.

Usnawiyah. (2012). Pertumbuhan dan Produksi Beberapa Varietas Kedelai (Glycine Max L.) dengan Pemberian Fungi Mikoriza Arbuskular Pada Tanah Salin [Tesis]. Medan : Program Pascasarjana, Universitas Sumatera Utara. 